\title{
NCSU Fellows Program lives up to its promise
}

The NCSU Libraries Fellows Program began its second year with the appointment of another stellar group of new librarians: Anne E. Pemberton, James Jackson Sanborn, and Lisa A. Sheets. The program identifies talented new graduates with MIS degrees and introduces them to career-enhancing opportunities in academic librarianship in a research library with strengths in science, technology, and digital library activities.

The Fellows Program is also intended to help the profession in general-during a time of declining numbers of MLS graduates coupled with rising competition for librarians from the private sectorby developing a pool of highly qualified professionals who wish to pursue careers in libraries.

Each fellow is appointed for a two-year term as a full member of the library faculty, based half-time in a home department and

and a 134-seat auditorium with data ports in every chair. The Gateway Commons, a fully electronic library, has staff ready to help students start their research in any subject. A cafe with indoor and outdoor seating provides space for a study break.

The Paterno family has long supported the libraties and they led the Campaign for the Library, which raised $\$ 13.75$ million in private funds to build a new library.

\section{More ACRL Friends}

ACRL would like to thank the following members for becoming Friends of ACRL.

\section{Century Club: Cary Sowell}

Friends: Lawrence McCrank

These members were inadvertently left off the list of Friends in the November issue. assigned to a special project for the other 20 hours per week. The library strives to ensure that the fellows help to meet library goals, as well as offering substantive work in areas of each candidate's personal interest and skills.

The success of this arrangement for both the library and the fellows is evident in the fact that every nember of the first group of fellows has already accepted a permanent faculty position on the library staff in a variety of positions, including digital projects, visual resources, and media

resources,

For more information about the NCSU Libraries Fellows Program, send e-mail to Wendy Scott, assistant director for Organizational Design and Learning (wendy_scottis ncsu.edu).-Iinnie Y. Davis, Nortb Carolina State University Libraries, jinnie_davis@ncsu. edu

The final $\$ 34.4$ million project included a combination of private, state, and university funds.

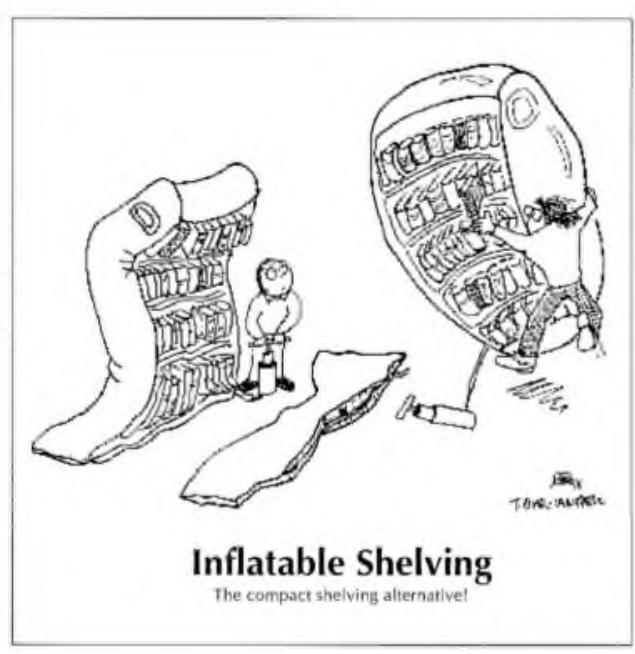

